\title{
SERICITE A LOW TEMPERATURE HYDROTHERMAL MINERAL.
}

\author{
Austin F. Rogers.
}

Of the various non-metallic minerals associated with ores, sericite is one of the most abundant and important. It is especially prominent in the wall rocks adjoining veins as emphasized by Lindgren in his classic paper, "Metasomatic Processes in Fissure Veins."1

While it is the general belief that sericite is of hydrothermal origin few attempts have been made to define its temperature range or to determine its age with reference to the other gangueminerals and ore-minerals. Apparently the necessary data have often been lacking. The general impression is that sericitization is contemporaneous with ore-deposition. ${ }^{2}$ In most of the cases where the relative age of sericite has been determined it has been assigned to an early stage of mineralization (Butler, Kirk, Irving and Bancroft, Spurr, and Stewart), while, on the other hand, the writer has found that it belongs to a late stage of mineralization, and that it is almost invariably formed after the sulphides.

That sericite is a comparatively low-temperature mineral formed at, or toward, the end of the hydrothermal period is the author's thesis. In addition to original descriptions of sericite, this paper also includes a review of opinions concerning the occurrence and origin of sericite.

The writer is indebted to his colleague, Professor C. F. Tolman, jr., for criticism of this article.

For any mineral there are two general classes of facts to be

1 Trans. Amer. Inst. Min. Eng., Vol. 30, pp. 578-692 (1900). Reprinted in Posepny volume, "Genesis of Ore Deposits," pp. 498-612.

${ }^{2}$ Lindgren, for example, says (Econ. GeoL., Vol. 2, p. 203, 1907) : "Neither is it apparent why these ascending solutions should not have deposited chalcopyrite and pyrite in the porphyry with simultaneous sericitization, such as generally takes place under influence of hot waters." 
established: (I) The properties of the mineral (crystallographic, physical, and chemical), and (2) the occurrence, association, and origin of the mineral (paragenesis in the broad sense ${ }^{3}$ ), or what Clarke ${ }^{4}$ has called the natural history of a mineral. Before the paragenesis or natural history of sericite is discussed, its properties will be briefly considered.

\section{PROPERTIES OF SERICITE.}

Sericite is the name given by $\mathrm{List}^{5}$ to a micaceous mineral oc-

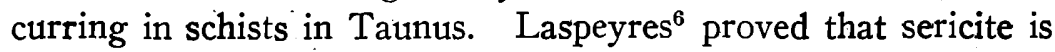
essentially identical with muscovite in chemical composition. Spurr $^{7}$ uses muscovite and sericite interchangeably. There is a possibility that fluorine is present in muscovite and absent in sericite, but very few complete analyses of sericite are available, and the fluorine determination is an especially difficult one.

Whether sericite is chemically identical with muscovite or not, another factor must be considered. An important part of mineralogical work in recent years has consisted in the reduction of varieties and synonyms. There is, however, a counter movement in the establishment of polymorphous modifications of the various naturally occurring chemical compounds. The phenomenon of polymorphism seems to be a general one, ${ }^{8}$ but comparatively few polymorphous minerals are known or recognized. Some of the varietal names of minerals must be elevated to the rank of mineral species, for example, adularia. It is possible that sericite is dimorphous with muscovite. There are differences in crystal habit (the crystals are thin tabular, and are apt to occur in elongated forms) and in certain optical properties such as the optic axial angle $\left(2 \mathrm{~V}=20^{\circ}\right)$. The differences in occurrence which are correlated with temperature are even more suggestive. At any rate, sericite is a useful term for the low temperature mineral with the approximate chemical composition of muscovite.

${ }^{3}$ Rogers, Econ. Geol., Vol. 7, p. 638 (IgI2).

4 Bull. 588 U. S. Geol. Surv., p. 7 (I914).

${ }^{5}$ Ann. d. Chem. u. Pharm., Vol. 81, p. 194 (1852).

${ }^{6}$ Zeit. für Kryst. u. Min., Vol. 4, p. 245 (1879).

? Professional Paper 42, U. S. Geol. Surv., p. 232 (I905).

8 Arzruni, Physikalische Chemie der Krystalle, p. 22 (I893). 
Sericite generally occurs as minute scales, fibers, or shreds, usually not distinctly visible to the naked eye. Distinct individual crystals are very rare, and sericite rarely develops except as a metasomatic mineral. An interesting exception has been studied by the writer. Euhedral crystals of sericite were found in a cavity in a specimen of altered monzonite collected at Bingham, Utah, by Mr. J. J. Beeson. These crystals are thin tabular pseudo-hexagonal with extinction parallel to one edge like muscovite.

Sericite has been found as a replacement of various silicates, especially the feldspars, and more particularly plagioclase. It is also a common replacement of quartz and occasionally of calcite. In the present paper the replacement of sulphides (pyrite, chalcopyrite, bornite, chalcocite, covellite, galena, and sphalerite) by sericite is described.

Among the characteristic optical properties of sericite are the variation in the relief in polarized light, the strong double refraction, the elongation parallel to slower ray, and the parallel extinction. The change of relief when rotated on the stage of the microscope is especially characteristic. Sericite, like muscovite, has moderate relief (in Canada balsam) when the elongation of the section is parallel to the vibration plane of the lower nicol and low relief when the elongation is perpendicular to the same. Fragments may be tested in clove oil $(n= \pm \mathrm{I} .535)$ when the change of relief is as given above. With bromoform ( $n= \pm$ I.597) the change of relief is even more marked, but in this case the sericite has moderate relief when the elongation is perpendicular to the vibration plane of the lower nicol and low relief when the elongation is parallel to the same. These tests follow from the optical constants of sericite which may be taken the same as those of muscovite:

$$
\left[n_{\gamma}=\mathrm{I} .597, n_{\beta}=\mathrm{I} .593, n_{\alpha}=\mathrm{I} .560 ; n_{\gamma}-n_{\alpha}=.037 ; c=\alpha .\right]^{9}
$$

When sericite occurs within feldspars and other crystals the interference colors are best observed by revolving the stage until the feldspar or other crystal host is in extinction position.

${ }^{9} \mathrm{I}$ use $\alpha, \beta$, and $\gamma$ for the axes of the optic ellipsoid, and $n, n$ and $n$ for the corresponding indices of refraction. 
Among minerals likely to be mistaken for sericite are kaolinite, chlorite, and calcite. Minute shreds of organic matter from Canada balsam may also at times resemble sericite. Kaolinite and chlorite have very weak double refraction and no variation in relief when rotated. Kaolinite is almost opaque white by reflected light, while sericite is transparent, but the opacity of kaolinite is probably due to the extremely small size of the individual crystals. Sericite is fusible, while kaolinite, if pure, is infusible. The water content of sericite is about 4.5 per cent., while that of kaolinite is about I4 per cent. In polished sections of the copper ores from the Engels mine, Plumas county, California, a choritic mineral occurs in lath-shaped sections so exactly like the sericite in other specimens, that thin sections are necessary to distinguish the sericite from chlorite.

THE OCCURRENCE OF SERICITE.

Sericite has been recognized in nearly all the types of oredeposits which seem to have any connection with igneous rocks, ranging from magmatic sulphide deposits and pegmatites through the deep high-temperature veins and deposits formed at intermediate depths to deposits formed near the surface. Its occurrence in these various classes of ore-deposits will now be discussed, beginning with the magmatic ores.

SERICITE ASSOCIATED WITH MAGMATIC ORES,
ENGELS MINE, PLUMAS COUNTY, CALIFORNIA.

The writer first observed sericite as a replacement of sulphides in specimens of magmatic copper ores from the Engels mine in Plumas county, California. ${ }^{10}$ The sericite occurs as definite, sharp-cut crystals which appear as lath-shaped sections. (See Figs. I, 2, 3, 4, 9, IO, and II.) The sericite replaces chalcopyrite, bornite, and chalcocite. Chalcocite usually appears in close association with sericite, and for this reason the writer decided (in the paper referred to) that chalcocitization was accompanied by sericitization. The study of additional specimens

${ }^{10}$ Econ. GeoL., Vol. 9, pp. 359-39I (I9I4). 


\section{EXPLANATION OF PLATE III.}

Specimens from No. 5 tunnel, Engel's mine, Plumas County, California. ( $s$, sericite; $b$, bornite ; $c c^{\prime}$, hypogene chalcocite ; $c c^{2}$, supergene chalcocite; $f$, feldspar; $t$, tourmaline.)

FIG. I. $(X 20$ diameters. $)$ Thin section. Sericite cutting bornite and chalcocite.

FIG. 2. ( $\times 57$.$) Polished section, showing bornite and chalcocite with$ sericite.

FIG. 3. ( $\times 700$.$) Polished section. Sericite cutting bornite-chalcocite area.$

FIG. 4. ( $\times$ I57.) Polished section. Sericite cutting bornite and bordered by chalcocite. 
Plate III.

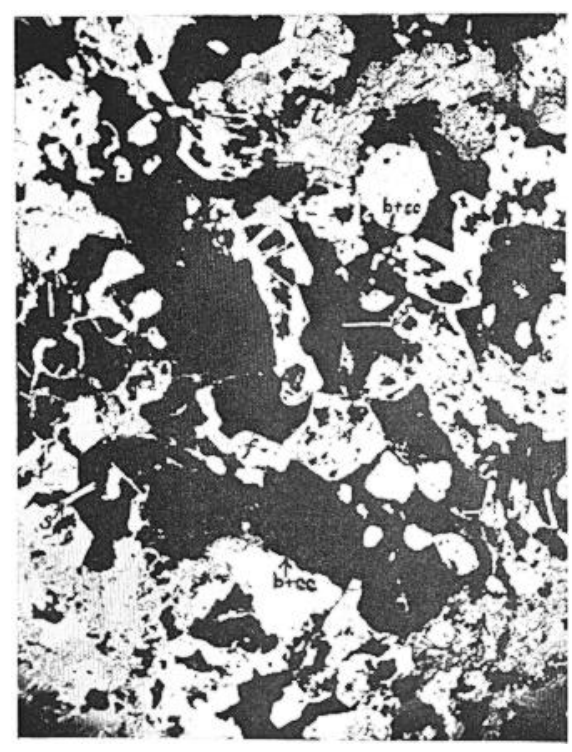

FIG. I.



FIG. 3 .
Economic Geology, Vol. XI.

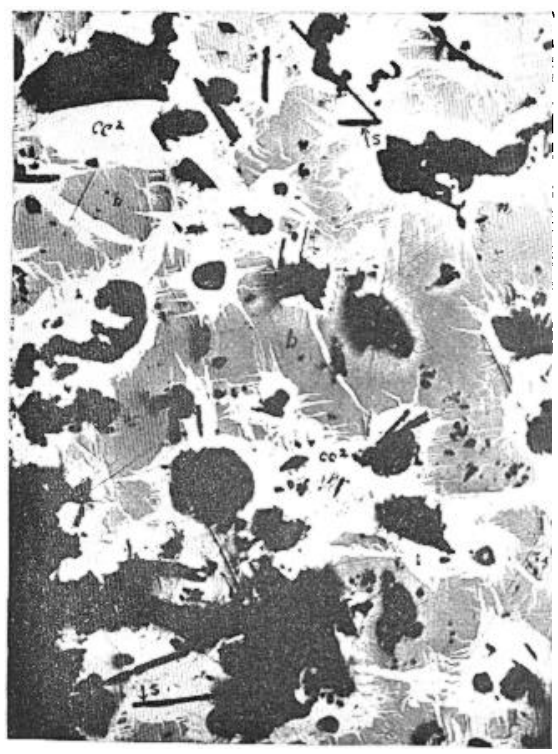

FIG. 2.

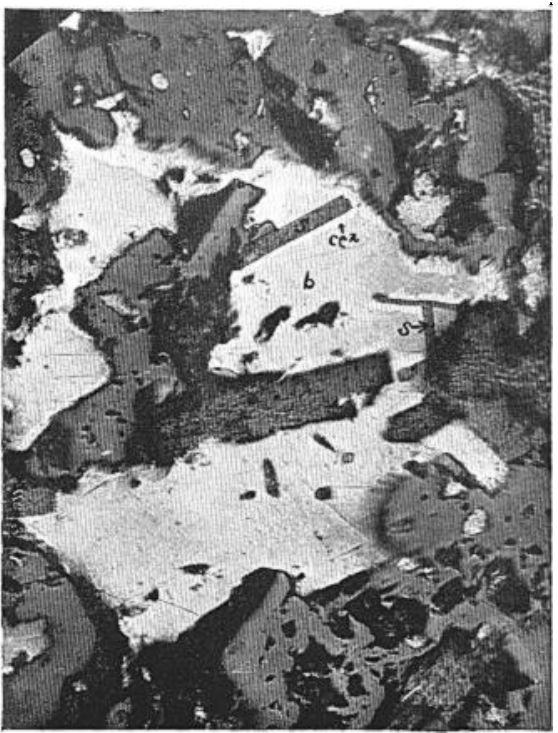

FIG. 4. 
recently received from the Engels mine caused a modification of this view. It may be stated, however, that the evidence in favor of "upward enrichment" of the bornite by chalcocite is even stronger than before. Further study of the Engels ores shows conclusively that there are two periods of chalcocite enrichment instead of one. The first generation of chalcocite is hypogene chalcocite formed before sericite (and chlorite), while the second generation of chalcocite is supergene chalcocite formed after the sericite (and chalcocite). In both cases chalcocitization is independent of sericitization.

There are several types of the chalcocite-enriched ores, all of which were formed from magmatic chalcopyrite or bornite, principally the latter.

Figs. I-4 are microphotographs of specimens from No. 5 tunnel. Fig. I represents a thin section showing sharp lathshaped sericite crystals cutting the opaque sulphides which are bornite and chalcocite. The light-colored mineral is largely plagioclase, in part sericitized. Tourmaline, chlorite, epidote, and quartz are also present.

Proof of two generations of chalcocite is furnished by Figs. 3 and 4. In Fig. 3 sericite cuts the irregular chalcocite-bornite area, showing it to be later, while in Fig. 4 the sericite crystals are bordered by chalcocite. In this case the bornite-sericite contacts have simply furnished capillary channels for the introduction of chalcocite-bearing solutions. In this specimen we have clear evidence of two generations of chalcocite, one formed before the sericite, the other after the sericite.

Figs. 6-8 are microphotographs of polished sections of another specimen from No. 5 tunnel of the Engels mine (No. I8 of Fig. 9I of the paper cited). This is a type quite different from that just described. Bornite has altered to covellite and bluish chalcocite, usually along crystallographic directions. Some sections show this type of alteration almost entirely free from sericite, which indicates that the chalcocite and covellite enrichment is independent of sericitization. Sericite occurs in these specimens, but the lath-shaped crystals are for the most part a colorless mineral of weak double refraction and negative elongation which is 


\section{EXPLANATION OF PLATE IV.}

Polished sections of specimens from Engel's mine, Plumas County, California. ( $c h$, chlorite; $b$, bornite; $c c^{\prime}$ hypogene chalcocite; $c c^{2}$, supergene chalcocite; $c v$, covellite; $c p$, chalcopyrite.)

FIG. 5. (X 125.) Chlorite cutting bornite and bordered by supergene chalcocite.

FIG. 6. (X I25.) Chlorite cutting bornite, chalcocite and covellite.

Fig. 7. ( $\times 375$.$) Chlorite replacing covellite and bornite.$

FIG. 8. ( $\times 375$.$) Chlorite replacing bornite and hypogene chalcocite and$ bordered by narrow rims of supergene chalcocite. 
Plate IV.

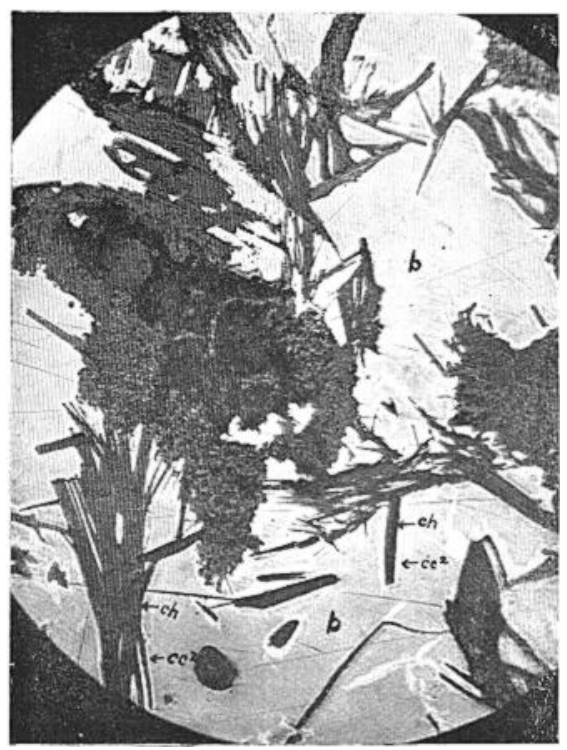

FIG. 5 .

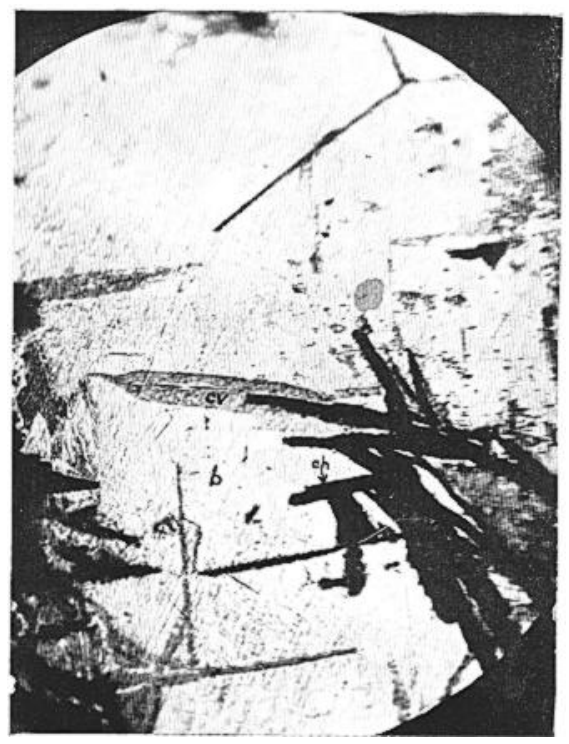

FIG. 7 .
Economic Geology. Vol. XI.

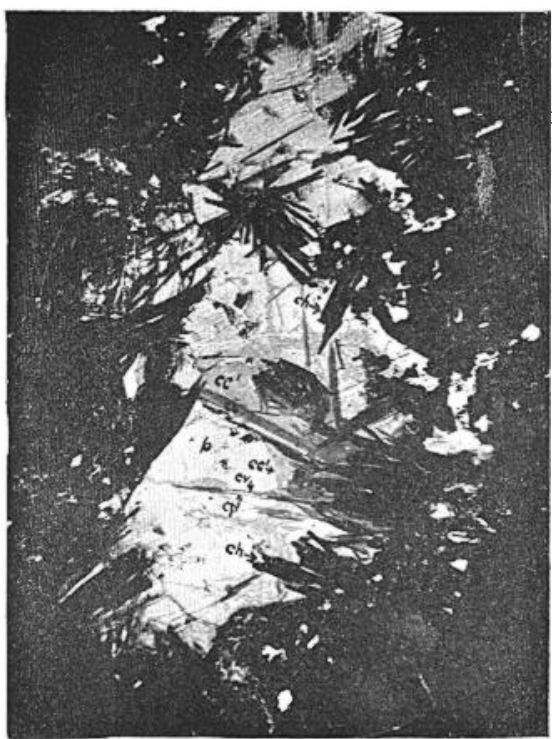

FIG. 6 .

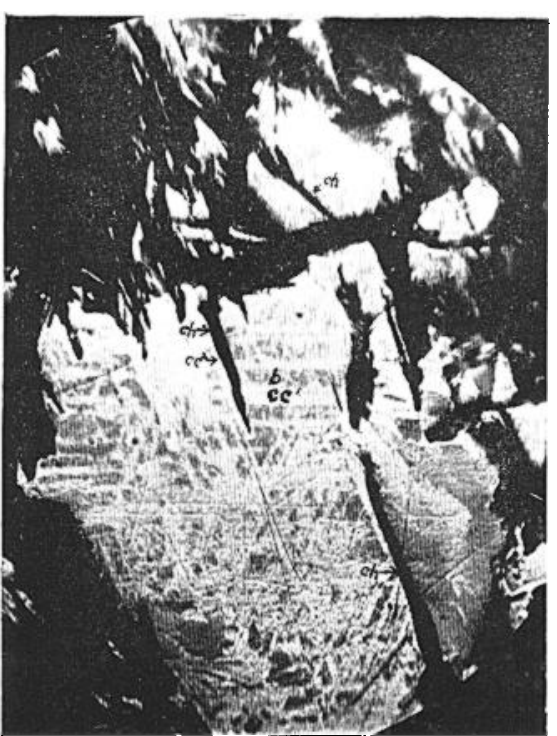

FIG. 8 . 
referred to the chlorite group (perhaps leuchtenbergite). What is true of the chlorite is also true of sericite, as the thin section proves that sericite is later than the chlorite. If the chlorite is later than the covellite and chalcocite the sericite is also. Fig. 6 illustrates a speck of sulphide surrounded and penetrated by chlorite crystals. The chlorite is later than chalcocite and covellite. Fig. 7 shows very plainly that the chlorite is later than covellite. This photograph was taken with a red screen (Wratten A) to bring out the covellite, and so the chalcocite does not show plainly. In Fig. 8, bornite has been altered to chalcocite along crystallographic directions and chlorite is later than chalcocite as well as bornite, for it cuts them indiscriminately. Very narrow rims of chalcocite occur along the chlorite laths where they are in contact with bornite, furnishing evidence of a second generation of chalcocite. This shows faintly in Fig. 8 (near the center).

A specimen from No. I tunnel is illustrated by Fig. 5. The lathshaped crystals penetrating the bornite are colorless chlorite but sericite also occurs in the same relation. The chalcocite here is later than the chlorite, and the bornite-chlorite boundaries have served as capillary channels for chalcocite-bearing solutions. The fact that the center of the veinlets is often occupied by quartz is an indication of the action of supergene solutions as is also the fact the chalcocite rims are sometimes bordered by melaconite. As further evidence of the supergene origin of the chalcocite, No. I tunnel is well within the oxidized zone determined by $\mathrm{Mr}$. $\mathrm{H}$. W. Turner. (See Fig. 92 of paper cited.)

Fig. 2 represents a polished section of a very rich copper ore ( $\mathrm{Cu}=43.9$ per cent.) which occurs along a leached zone in No. 5 tunnel (No. 39 of Fig. 9I of paper cited). The sericite has replaced bornite, but it is evident that the chalcocite is a later introduction. As evidence that chalcocite formation is independent of sericitization, note that chalcocite occurs around minerals other than sericite which are mostly hematite. The chalcocite is probably due to an advanced stage of alteration brought about by supergene solutions. The alteration to chalcocite along crystallographic directions of the bornite is very marked in this advanced stage. 
Two periods of chalcocite enrichment are well marked in the Engels ores, hypogene chalcocite formed before the sericite, and supergene chalcocite after the sericite. As sericite antedates the supergene chalcocite and is independent of it, the sericite is in all probability a hydrothermal mineral.

OOKIEP, SOUTH AFRICA.

Sericite was also ghserved cutting into chalcopyrite anhedra in thin sections of magmatic ores from the East Mine at Ookiep, Namaqualand, South Africa kindly furnished me by Dr. A. W. Rogers, Director of the Geological Survey of South Africa. Here the chalcopyrite is a magmatic mineral and there is nothing to determine how much later the sericite is.

\section{SILVER PEAK, NEVADA.}

Spurr ${ }^{11}$ in discussing alaskite from Silver Peak, Nevada, concludes that sericitization of the feldspars "took place when the magma was partially consolidated and before the deposition of the remainder (of the feldspar) which formed the second generation." This seems very improbable, for it practically makes sericite a magmatic mineral. There seems to be no definite proof that the sericitization has taken place before the consolidation of the magma. For one thing the evidence of two generations of orthoclase is not conclusive. It may be that what is called fresh orthoclase, " $o$ " of Fig. $A$, pl. XX. of Spurr's report, is plagioclase (andesine-oligoclase) cut so that twinning does not show. It is a well-known fact that some feldspars are altered while other feldspars in the same rock are unaffected. The gradation in the size of the crystals possibly indicates that the alteration began with coarse muscovitization, the crystals becoming smaller and smaller as the temperature gradually decreased, finally ending with sericitization.

11 Professional Paper 55, U. S. Geol. Surv., p. I07 (1906). 
SERICITE ASSOCIATED WITH CONTACT METAMORPHIC ORES.

Stewart ${ }^{12}$ describing the Silverbell, Arizona, contact deposits, stated that the sericite of the intrusives was formed at the same time as the silicates (garnet and wollastonite) of the contact zone, but earlier than the sulphides (pyrite and chalcopyrite) of the contact zone. The criteria for this conclusion are not given. The statement may well be doubted, for Lindgren has shown that at Morenci hydrothermal metamorphism (sericite present) is later than contact metamorphism (sericite absent).

Umpleby $^{13}$ mentions sericite in the wall rock of contact deposit at Mackay, Idaho, but ascribes it to hydrothermal alteration.

\section{SERICITE IN HIGH TEMPERATURE VEINS.}

Sericite has been described from the walls of pipe-like tinbearing veins of south Africa. ${ }^{14}$

At Silver Mines, Madison county, Missouri, Haworth ${ }^{15}$ found sericite intimately associated with topaz in the wall rocks of a vein containing galena, wolframite, zinnwaldite, fluorite, and quartz.

A specimen from the Bryan mine, Missoula county, Montana, obtained from Professor D. C. Bard, of Butte, consists mainly of quartz with galena and a little tourmaline. This must belong to the lead-tourmaline type of veins recently described by Knopf. ${ }^{16}$ The galena replaces quartz and sericite replaces galena. The sericite crystals are in approximately parallel position. This indicates its development under pressure or stress.

Among the copper-tourmaline deposits the Cactus mine, San Francisco district Utah, is prominent. Butler ${ }^{17}$ places the sericite of the monzonite of the Cactus mine near the beginning of mineralization and before the development of tourmaline and hematite. He says:

12 Trans. Am. Inst. Min. Eng., Vol. 43, p. 240 (I9I2).

13 Econ. Geol., Vol. 9, p. 321 (Igl4).

14 Ferguson and Bateman, Econ. GeoL., Vol. 7, p. 235 (1912).

${ }^{15}$ Missouri Geol. Surv., Vol. 8, p. 158 (I895).

16 Econ. Geol., Vol. 8, p. I05 (I9I3). .

17 Professional Paper 80, U. S. Geol. Surv., p. I2I (I9I3). 
"The sericitization of the monzonite must have been nearly completed before the deposition of the tourmaline, as it is hardly probable that the solutions which brought in the tourmaline could have penetrated and altered the wall rock to any considerable extent without depositing tourmaline."

This is simply an argument that sericite and tourmaline were not simultaneous, but as far as the evidence goes sericite may have been later than the tourmaline. If the words sericite and tourmaline are interchanged and tourmalinization substituted for sericitization in the above quotation, the argument is equally effective.

Sericite is also present in the gold-tourmaline veins of Meadow Lake, Nevada county, California, described by Lindgren. ${ }^{18}$

Sericite occurs in the Passagem lode in Brazil which Hussak regarded as a pegmatite dike. Derby ${ }^{19}$ regards it as a pegmatite that has been fractured and subsequently mineralized by sulphides. In regard to the sericite he says :

"The fissures of the fractured quartz-feldspar rock are here of considerable width and the filling is exclusively of tourmaline with only here and there a small crystal of pyrite. The feldspar is completely sericitized and it is clear that the effect was produced by the agent that introduced the tourmaline rather than the one that brought in the metallic sulphides."

As far as the evidence goes the sericitization may have been contemporaneous with pyritization or even later.

In the gold-telluride veins of western Australia sericite is a prominent mineral. In a thin section from a typical specimen from this district (mine unknown), sericite proves to be later than pyrite, which in turn is later than chlorite.

In the gold-quartz veins occurring in albite-diorite at the Treadwell mine, Alaska, which form a connecting link between the high temperature veins and those formed at intermediate deposits, sericite occurs as a metasomatic alteration of feldspars.

18 “Mineral Deposits," p. 656.

19 Amer. Jour. Sci. (4), Vol. 32, p. I85 (1911). 
SERICITE IN DEPOSITS FORMED AT INTERMEDIATE DEPTHS.

In ore-deposits formed at intermediate depths, sericite reaches its greatest development. The wall-rocks are often converted into altered products containing from 40 to 60 per cent. or more of sericite.

GOLD-QUARTZ VEINS OF CALIFORNIA.

In the gold-quartz veins of the Sierra Nevada, California, sericite is common, especially in the wall-rocks as emphasized by Lindgren.

In a pyritized rock containing albite crystals in cavities from the Harvard mine, Jamestown, Tuolumne county, California, the writer has observed the following successions of minerals: (I) albite, (2) quartz, (3) dolomite, (4) pyrite, (5) sericite. Rhombohedral crystals of dolomite were formed by the metasomatic replacement of quartz. In other spots the sericite cuts dolomite and the sericite is later than pyrite. At one point a slender sericite crystal abuts against the pyrite but has been deflected to one side.

The writer has examined thin sections of a specimen from Calaveras county, California (exact locality unknown), containing large $(2 \mathrm{~cm}$.) pyrite cubes. The section consists largely of albite with some quartz, calcite, chlorite, and sericite. The sericite is very prominent and cuts albite, quartz, chlorite, and calcite. As films of sericite coat the surface formed by the pyrite crystals in contact with their matrix the sericite is also later than the pyrite. Acicular crystals of apatite are present in several places. This apatite is not residual from an igneous rock but is undoubtedly a hydrothermal mineral. Similar apatite has been described by $\mathrm{Knopf}^{20}$ in altered albite-diorite from the Eagle River region, Alaska. The prominence of albite places the gold-quartz veins of the Mother Lode near the southeastern Alaska type that has generally been recognized.

In the mineralogical collection of Stanford University there is a remarkable specimen of sericite from the Longfellow mine, Big 20 Bulletin 502, U. S. Geol. Survey, p. 37 (1912). 
Oak flat, Tuolumne county, California. This is a mass of white to gray sericite scales which was evidently packed in a box when taken from the mine in a wet condition. The plastic mass has taken on the shape of the box. Quartz crystals of various sizes are distributed through the mass. The sericite forms a thin film around the quartz. The sericite is formed after the quartz and has every appearance of being a late development. The apparently pure sericite masses contain small quartz subhedra as shown in thin sections. The quartz has evidently been corroded by the sericite-forming solutions and replaced to some extent, for thin films of sericite are occasionally present within the solid quartz crystals. Three subhedra of quartz noted in the thin section evidently represent the remnants of an original crystal which has been severed by sericite. Two of them extinguish together, while the third has been slightly displaced. The slight displacement during replacement of portions of crystals originally parallel I believe to be a rather common phenomenon. The effect of pressure is evident in the fact that the quartz crystals are in approximately parallel position.

\section{BUtTe, montana.}

At Butte sericite is very common in the altered wall rocks as has been pointed out by Weed, ${ }^{21} \mathrm{Kirk},{ }^{22}$ and Ray. ${ }^{23}$ Kirk, especially, devoted a good deal of attention to sericite. He places sericite at an early period of mineralization as may be seen from the following statement. ${ }^{24}$

"The earliest mineralizers were rich in silica and the components of sericite and pyrite and so filled the rocks with these as to exclude the copper deposition coming later on."

Ray $^{25}$ expresses practically the same opinion.

"The first solution effected sericitization, silicification, and pyritization of the quartz-monozite."

21 Prof. Paper 74, U. S. Geol. Surv., p. 87 (Igr2).

22 Econ. Geol., Vol. 7, p. 35 (I9I2).

28 ECON. Geol., Vol. 9, p. - (IgI4).

24 Loc. cit., p. 8I.

25 Econ. GEoL., Vol. 9, p. 469 (I9I4). 
Ray's conclusion is evidently based upon specimens such as represented by Fig. $B$, Plate $\mathrm{X}$. of his article. A veinlet consisting of sulphides has apparently replaced sericite, but there is a possibility that the sulphides have been replaced by sericite and that the apparent veinlets are simply remnants.

Through the kindness of Mr. Ray I have been able to study some of the Butte specimens. The specimen studied in detail is from the 2,200-foot level of the Speculator mine. A photograph of a polished section is shown in Fig. I2. On casual study the relations of the bornite and chalcocite to the sericite admit of two interpretations (i.e., sericite is earlier than the sulphides or vice versa). It is only by long, careful study that the matter has been settled to the satisfaction of the writer. In Fig. I2 the gray mineral in the left lower corner is sericite. At the left upper corner and in the center are bornite and chalcocite. At the lower right corner there is a little residual pyrite. The invasion of bornite-chalcocite by sericite is unmistakable, and there can be little doubt that spaces now occupied by sericite were once bornite and chalcocite. Notice the irregular bornite-sericite contacts and the remnants of bornite within the sericite. It is also evident that the chalcocite, whatever its origin, was formed before the sericite, as its distribution is in no way related to the present boundaries of the sulphides. The sericite cuts the bornite and chalcocite indiscriminately. In this specimen gashes of late hypogene chalcopyrite which cut the bornite and which were once continuous are now found to be severed by sericite.

Microscopic work proves that the deep-seated chalcocite is the latest of the hypogene minerals in the Butte deposits. Since sericite is later than the chalcocite it follows that the sericite at Butte was formed at, or toward, the close of the hydrothermal period. That it is a hydrothermal mineral at Butte scarcely admits of doubt in view of Kirk's work. As the sericite follows the chalcocite stage we have definite proof that the deep-seated chalcocite at Butte is formed by "upward enrichment." This confirms the opinion expressed by the writer in December, $1913,{ }^{26}$

26 Econ. GeoL., Vol. 8, p. 78I (I9I3). 


\section{EXPLANATION OF PLATE V.}

Thin sections and polished sections from various localities. ( $s$, sericite; $q$, quartz; $b$, bornite; $c p$, chalcopyrite; $c c^{\prime}$, hypogene chalcocite; $c c^{2}$, supergene chalcocite; $p$, pyrite.)

FIG. 9. (X90.) Thin section, Copper Flat, Ely, Nevada. Chalcopyrite cut by sericite.

FIg. I0. ( $\times 45$.$) Polished section. Person Consolidated Mine, Virgilina$ district. Bornite and hypogene chalcocite cut by sericite. Rims of supergene chalcocite between bornite and sericite.

FIG. II. (X I25.) Polished section. "Pay-roll" porphyry, Bingham, Utah. Bornite, supergene chalcocite, quartz, and sericite in altered quartz-monzonite.

FIG. 12. (X I40.) Polished section. Speculator Mine (2,200-ft. level), Butte, Montana. Sericite replacing bornite and hypogene chalcocite. 


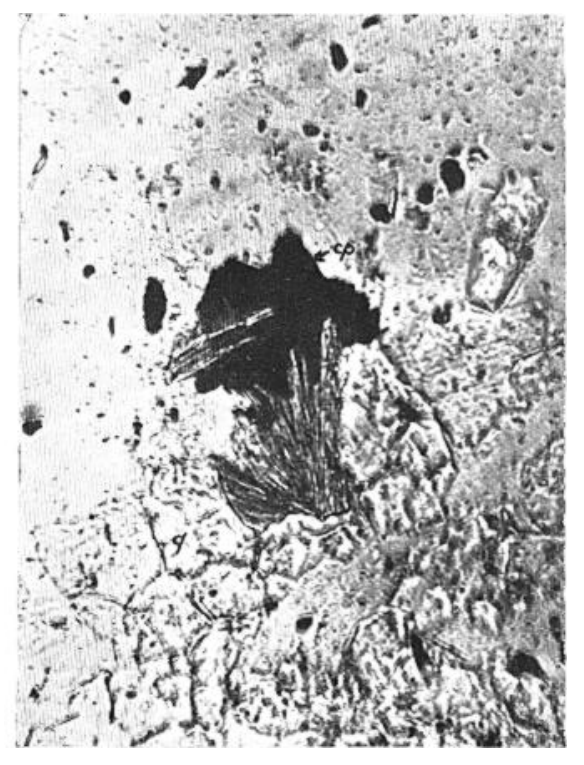

Fici. 9 .

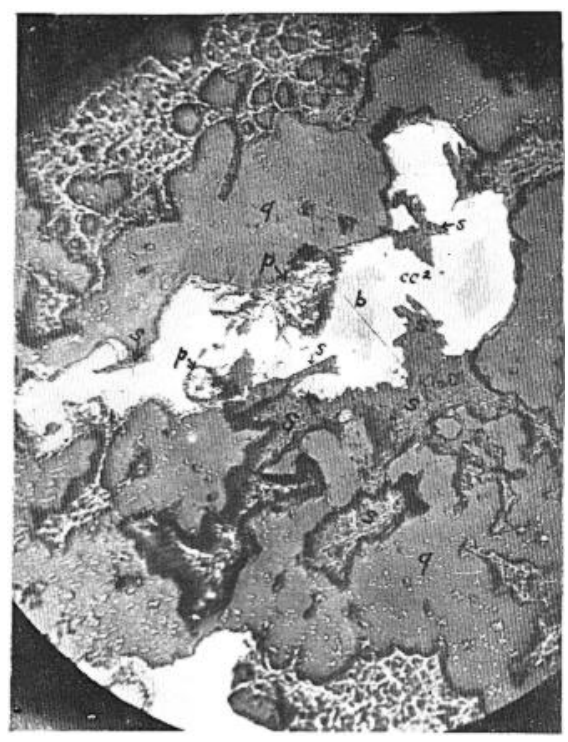

FIG. II .

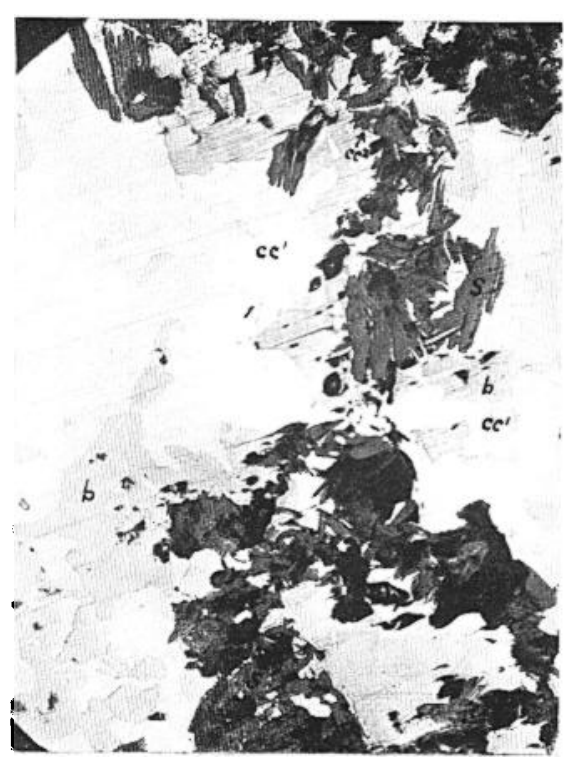

FIG. IO.

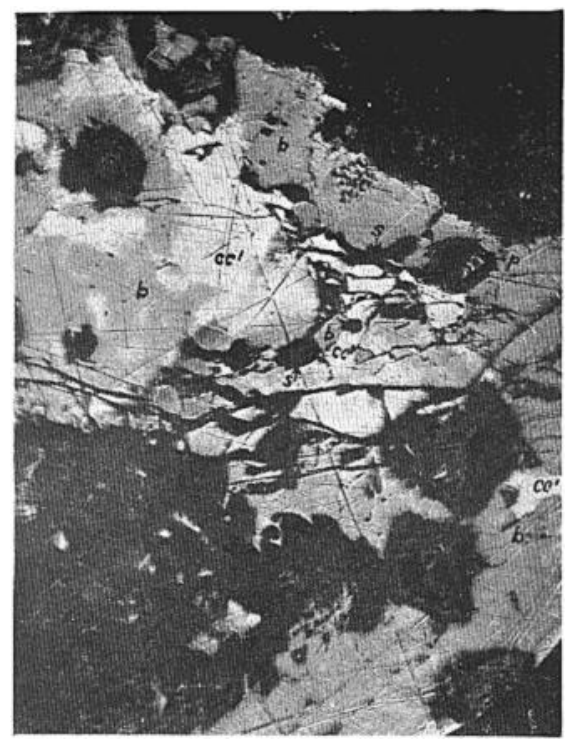

FIG. I 2 . 
which was based upon microscopic work as combined with the geological work of Sales.

BINGHAM, UTAH.

The writer is indebted to Mr. J. J. Beeson, one of his students, for an opportunity to study sections of the disseminated quartz monzonite-porphyry copper ores from Bingham, Utah. Sericite is a prominent mineral in these ores. It occurs as a replacement of feldspars, quartz, and sulphides. Fig. I I is a microphotograph of a polished section of the "pay roll" porphyry from the Boston Consolidated mine. The transparent minerals are quartz and sericite. The opaque minerals are pyrite, bornite, and chalcocite. The sericite is clearly a replacement of the sulphides. Note that lath-shaped sericite crystals penetrate the sulphides. Contrast the rough sericite-sulphide contacts with the smooth quartz-sulphide contacts. The sericite area in the lower right center of the photograph was once occupied by sulphides. The chalcocite here is an alternation product of bornite. The only question is whether the sericite was formed before the chalcocite or after it. In other specimens Mr. Beeson ${ }^{26 a}$ has found that sericite crystals which cut bornite and chalcopyrite are bordered by narrow rims of chalcocite with needles of covellite. Occasionally sericite in the center of chalcopyrite has no chalcocite or covellite around it. $\mathrm{Mr}$. Beeson concludes that chalcocite and covellite are later than sericite and that the sericite-bornite and sericite-chalcopyrite contacts have simply furnished capillary channels for the later solutions. A careful study of Fig. I I also confirms the opinion that the sericite is earlier than the chalcocite. The chalcocite occurs as a wide border around the bornite remnants at the right center of the photograph. This chalcocite border was formed from solutions which surrounded the present sulphide area and not the original sulphide area which is now in part sericite. The chalcocite is almost certainly supergene in origin. In the Bingham disseminated copper ores sericite was formed after the bornite, and this places it toward the close of the hydrothermal period.

26a Bull. Am. Inst. Min. Eng., p. 2228 (Nov., I915). 
Euhedral pseudohexagonal crystals of sericite in an altered quartz-monzonite were collected by Mr. Beeson at Bingham.

\section{ELY, NEVADA.}

Only a few sections of the disseminated copper ores from Ely have been studied but the evidence, as far as it goes, indicates that the sericite is a rather late hydrothermal mineral. These specimens, which are from Copper Flat, were kindly furnished us by Professor A. C. Lawson, of the University of California. Fig. 9 represents a speck of chalcopyrite in the silicified quartz-monzonite which has been penetrated by sericite.

A specimen of massive pyrite with a thin black film, which is probably chalcocite, has been cracked and the cracks filled with thin films of typical sericite. The sericite is undoubtedly later than the pyrite, but the thin coating of chalcocite is probably later than sericite, and the sericite has furnished capillary channels for the chalcocite-forming solutions.

\section{VIRGILINA DISTRICT.}

The copper ores of the Virgilina district of North Carolina and Virginia consist of bornite and chalcocite in a gangue of quartz. Epidote, chlorite, and sericite are also present.

The writer has studied polished sections and thin sections from the Blue Wing mine and from the Person Consolidated mine (formerly the Durgy), Person county, N. C. These were obtained respectively from the California State Mining Bureau and from Dr. T. L. Watson, of the University of Virginia, to whom I would express my thanks.

A polished section of the ore from the Person Consolidated mine is illustrated in Fig. ro. The sulphides are bornite, and chalcocite; the non-metallic mineral is sericite, proved by optical properties in thin sections. Viewed with a lower power lens this section exhibits elongated areas of bornite-chalcocite. The photograph shows one of these almost cut across by sericite. The sericite is later than bornite and also later than the chalcocite, and this is true whether the chalcocite is due to re- 
placement of the bornite or to a simultaneous development of bornite and chalcocite. The sericite cuts across the bornite patches and chalcocite areas indiscriminately and the distribution of the two sulphides has no relation to the sericite. There are, however, two generations of chalcocite for the narrow rims of chalcocite around the bornite are undoubtedly later than the sericite.

In further support of the evidence that the sericite is formed between the two generations of chalcocite, Figs. I3-I6 from a polished section of a specimen from the Blue Wing mine are presented.

In Figs. I3 and I4 the non-metallic minerals include sericite, chlorite, and quartz. The sericite and chlorite are indistinguishable by the metallographic microscope, but by reflected light with the ordinary microscope they may be distinguished by the fact that the sericite is greenish-white and the chlorite dark green. In thin sections the sericite clearly cuts the chlorite. Two generations of chalcocite are distinguishable, the first generation occurring as irregular areas with bornite, and the second generation as narrow rims around the bornite. A slight color difference in the two kinds of chalcocite can be detected in the lower part of the photographs, but can scarcely be detected in the half-tone. Fig. I4, which is an enlarged view of the lower part of Fig. I3, shows plainly the replacement of the bornite and chalcocite of the first generation by the sericite and also that the second generation of chalcocite is later than the sericite.

Figs. 15 and 16 furnish even better evidence of the same facts. A patch of the earlier chalcocite has been cut across by a veinlet with quartz center which has developed later chalcocite within the bornite. This is conclusive evidence of two generations of chalcocite. This checks the work of Laney ${ }^{27}$ who also found two generations of chalcocite in the Virgilina ores. Fig. 16 is a higher magnification of the top of Fig. I5. An irregular chalcocitebornite area has been truncated by sericite and chalcocite of the second generation has been deposited in rims around the bornite. In Figs 15 and 16 all the non-metallic mineral is sericite.

27 Econ. Grol., Vol. 6, p. 399 (I9II). 


\section{EXPLANATION OF PLATE VI.}

Polished sections of a specimen from the Blue Wing Mine, Virgilina district, North Carolina-Virginia. ( $s$, sericite; $c h$, chlorite; $b$, bornite; $c c^{\prime}$, hypogene chalcocite; $c c^{2}$, supergene chalcocite.)

FIG. 13. $(\times 40$.$) Bornite and hypogene chalcocite cut by sericite and$ chlorite.

FIG. I4. ( $X$ I25.) Magnified view of the lower part of Fig. I3.

FIG. 15. $(\times 40$.$) Bornite and hypogene chalcocite cut by sericite and$ supergene chalcocite velnlets with quartz centers. Ruins of supergene chalcocite around bornite.

Fig. I6. ( $X$ 125.) Magnified view of upper part of Fig. I5. 
Plate Vi.

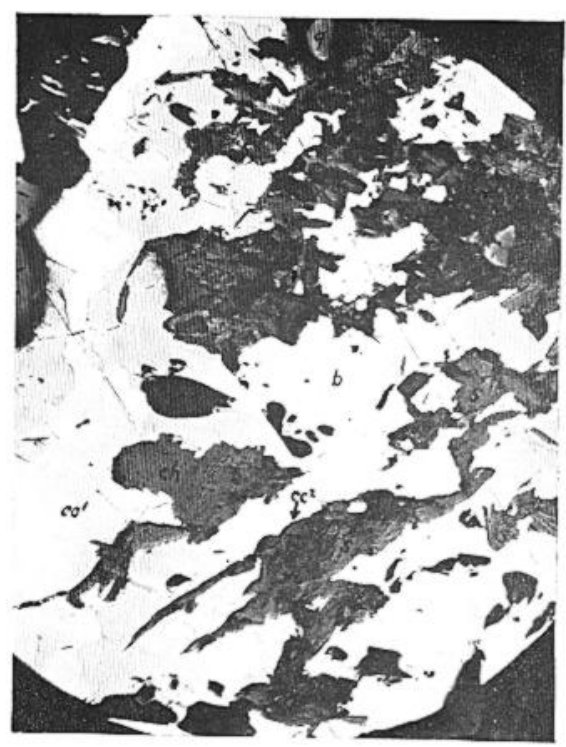

Fig. I 3 .

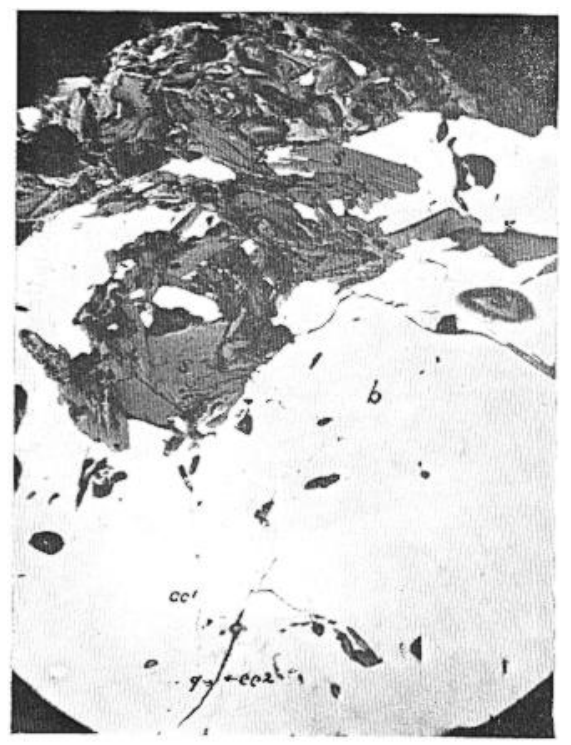

FIG. I5.
Economic Geology. Vol. XI.

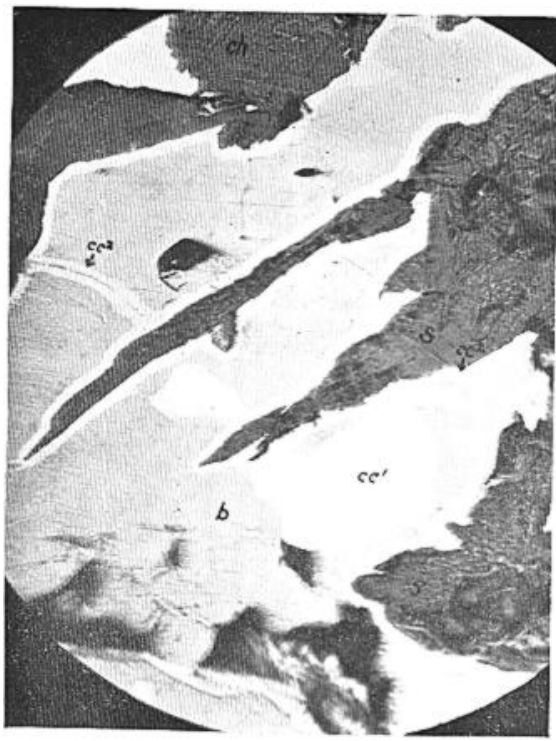

FIG. I4.

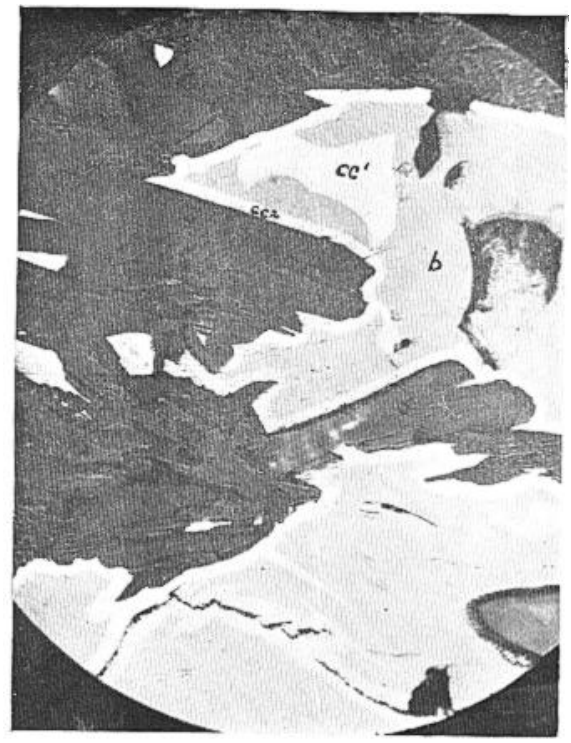

FIG. 16. 
The second generation of chalcocite is probably of supergene origin as definite veinlets occur often with quartz centers. The first generation of chalcocite is almost certainly hypogene in origin.

SERICITE IN DEPOSITS FORMED NEAR THE SURFACE.

In Lindgren's division of ore-deposits formed near the surface by ascending thermal solutions, sericite though usually present in fair quantities is not often abundant. Its place seems to be taken in part by adularia, which is of the same general composition. But at Tonopah, Cripple Creek, Jarbridge (Nevada), Rawhide (Nevada), De Lamar (Idaho), and Silver City (Idaho), and in the Thames district, of New Zealand, sericite occurs with adularia. At Lake City (Colorado), Silverton (Colorado), and Nagyag (Hungary) sericite occurs without adularia. At Lake City, according to Irving and Bancroft, ${ }^{28}$ pyrite, silica, and sericite represent the earliest stages of vein formation.

The writer has examined a thin section of an altered rhyolite (or possibly dacite) from Rawhide, Nevada. ${ }^{29}$ The orthoclase phenocryst has been partly altered to sericite, while in the groundmass rhombic crystals of adularia occur along with quartz anhedra. Though the sericite and adularia occur together they are probably not formed simultaneously, for they represent different types of alteration. The relative age of the two minerals in the Rawhide specimens can not be determined. Spurr ${ }^{30}$ referring to adularia and sericite at Tonopah says:

" That one of these products is not an alteration product of the other is shown by the fact that they are often intercrystallized, each mineral being perfectly fresh."

But this does not prove that they were formed simultaneously. There are, however, hints in the literature that sericite may be later than adularia. Lindgren and Ransome, ${ }^{31}$ speaking or latitephonolite in Cripple Creek, say:

28 Bull. 478, U. S. Geol. Surv., p. 44 (I9I I).

${ }^{29}$ What was called sericite in an adularia-quartz vein at Rawhide, by the writer (ECon. Grol., Vol. 6, p. 790, I9II), proves to be calcite.

30 Prof. Paper 42, U. S. Geol. Surv., p. 227 (I905).

31 Prof. Paper 54, U. S. Geol. Surv., p. I89 (I906). 
"In one place fibers of sericite project into the adularia."

Umpleby ${ }^{32}$ in the description of the Parker Mountain district in Ĺemhi county, Idaho, says:

"Sericite in quartz is probably, in part at least, derived from adularia."

The deposits formed near the surface in connnection with igneous rocks are formed at temperatures ranging from about $50^{\circ}$ C. to $150^{\circ} \mathrm{C}$., according to Lindgren. ${ }^{33}$ The presence of sericite in these deposits, then, is further evidence that it is a rather low temperature mineral, and if, as seems probable, sericite is later than the adularia, there is evidence of still lower temperature.

The occurrence of sericite in these low temperature deposits is of more significance than its occurrence in high temperature deposits such as deep veins and magmatic sulphide ores, for its formation did not necessarily take place along with the deposition of ores and the high temperature gangue minerals. Evidence rapidly accumulating, especially from the microscopic side, makes it certain that often the minerals of an ore deposit are successively formed at gradually decreasing temperatures. This has been brought out by Spurr and Garrey ${ }^{34}$ in a valuable paper. The same fact is evident in a study of the Butte ores now being made at Stanford University by Mr. J. C. Ray and a microscopic study of many types of copper sulphide ores has convinced me that it is safe to assume this as a generality.

THE OCCURRENCE OF SERICITE IN METAMORPHIC ROCKS.

Sericite is a common mineral in some kinds of metamorphic rocks, especially certain schists and gneisses. It seems to be the general belief that sericite in metamorphic rocks is the product of dynamic metamorphism. Clarke, ${ }^{35}$ speaking of sericitization, says :

"The alteration is most conspicuous in regions where the dynamic 32 Bull. 528, U. S. Geol. Surv., p. 79 (igi3).

38 "Mineral Deposits," p. 138 (I9I3).

34 Econ. Geol.; Vol. 3, p. 687 (I908).

${ }^{35}$ Bull. 49I, U. S. Geol. Surv., p. 567 (IgII). 
metamorphism has been most intense-high temperature; the chemical activity of water and mechanical stress all working together to bring it about."

G. H. Williams ${ }^{36}$ says :

"Sericitization is therefore a phenomenon of dynamic metamorphism."

Grubenmann in a recent work ${ }^{\mathbf{3 7}}$ on the metamorphic rocks places the sericite-bearing rocks (sericitphyllit, sericitalbitgneise, sericitquartzit, etc.) in the Epi-division formed in the upper zone of metamorphism under conditions of moderate temperature, small hydrostatic pressure, and strong stress.

The only very careful study of sericite in metamorphic rocks that has come to my notice is de Lapparent's ${ }^{38}$ paper on some of the French porphyroids. This contribution to our knowledge of sericite is one of the most important that has yet appeared. De Lapparent makes positive statements to the effect that sericite is later than the period of dynamic metamorphism:

"Le séricite dont il est ici question est postérieure à l'époque ou les phénomènes dynamiques se sont produits . . . ${ }^{39}$

et de plus qu'elle n'est

pas un minéral de transformation dynamométamorphique, mais qu'elle est due à la circulation lente des eaux." 40

Laughlin ${ }^{41}$ comes to the conclusion that sericite in a gneissoid alaskite at Lantern Hill, Connecticut, is of later development than the gneissic structure and is not due to dynamic metamorphism.

The writer has examined a thin section of a sericite gneiss from Bonnie Doon near Santa Cruz, California, collected by Mr. C. A. Waring. The two principal minerals are the quartz and sericite. The sericitized areas undoubtedly represent original feldspars. Sericite has also formed at the expense of the quartz and the unknown mineral. It is clear that sericitization was subsequent

${ }^{86}$ Bull. 62, U. S. Geol. Surv., p. 60 (I890).

${ }^{37}$ Die Kristallinen Schiefer, 2d ed., IgIo.

${ }^{38}$ Bull. fr. soc. min., Vol. 32, p. 174 (1909).

39 Loc. cit., p. 215.

${ }^{40}$ Loc. cit., p. 301.

41 Bull. 492, U. S. Geol. Surv., p. 140 (1912). 


\section{EXPLANATION OF PLATE VII.}

Thin sections of rocks from Marquette, Michigan (Fig. I7), and Mound House, Nevada (Figs. 18 , 19, 20). ( $s$, sericite; $q$, quartz; $m$, muscovite; $a$, anhydrite; $g$, gypsum ; $c$, calcite.)

FIG. I7. ( $\times$ 30.) Quartzite with original sand grain $(q)$ and second enlargement $\left(q^{\prime}\right)$ cut by sericite.

FIG. I8. (X 12.) Anhydrite altering to gypsum with original calcite.

FIG. I9. ( $\times$ 30.) Sericite in recrystallized gypsum with remnants of original calcite.

FIG. 20. ( $X 24$.$) Muscovite in compact gypsum with remnants of origi-$ nal calcite. 
Plate Vil.

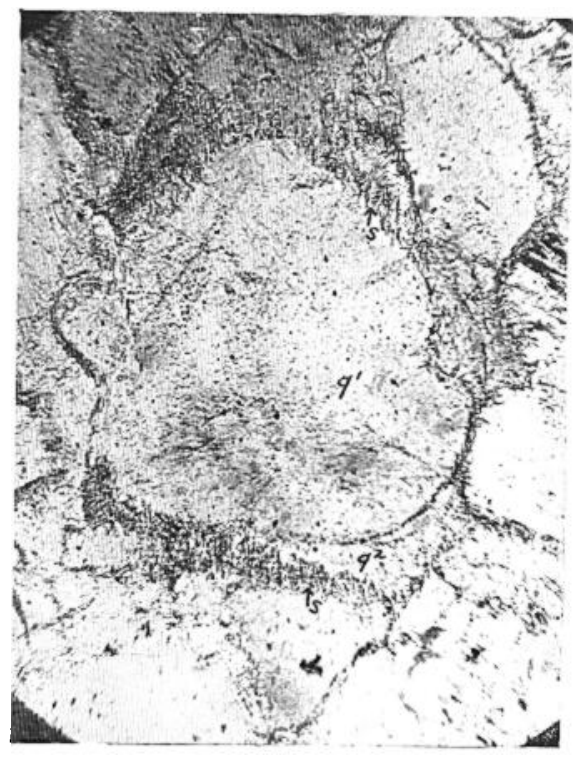

FIG. I 7.

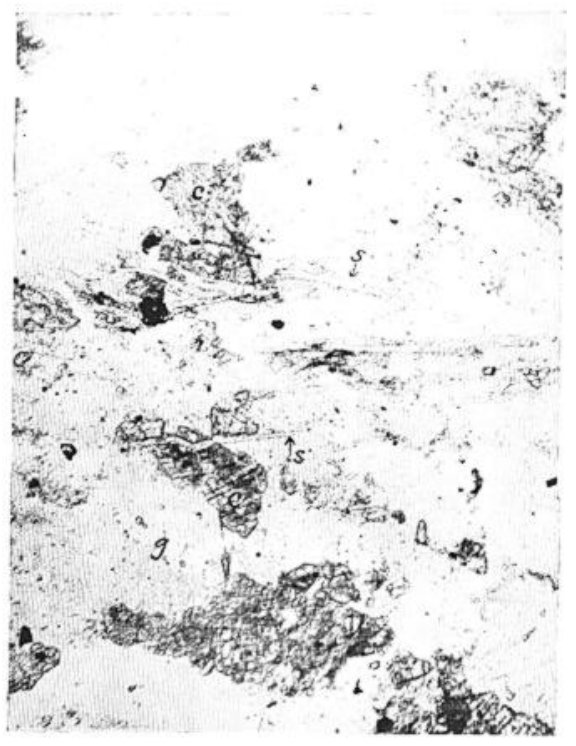

FIG. I9.

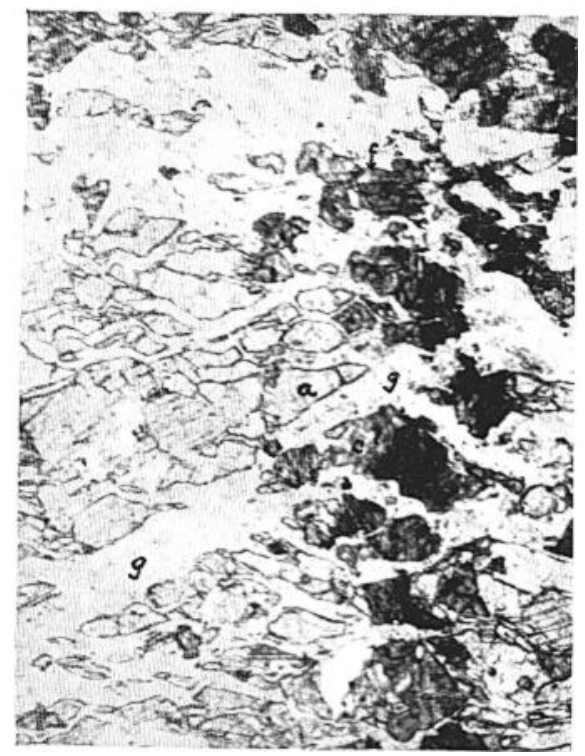

FIG. I 8 .

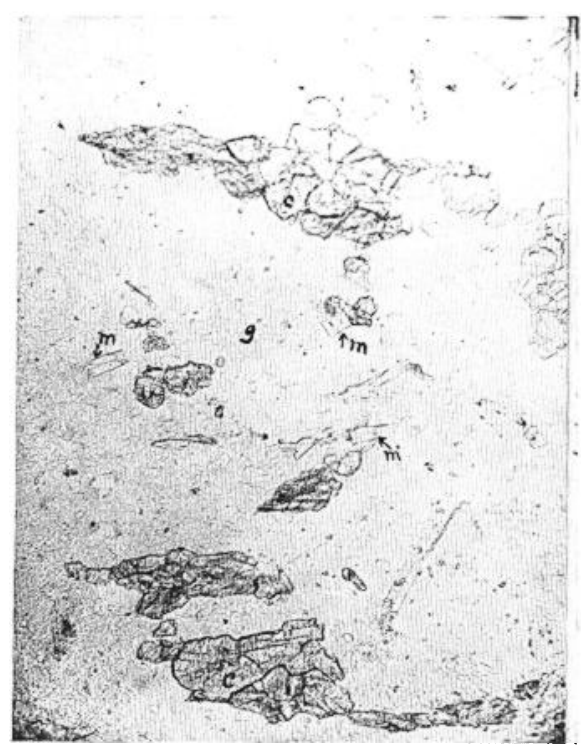

FIG. 20. 
to the main period of metamorphism at which time the quartz and feldspar were crystallized or recrystallized.

A thin section of graphite gneiss from Hague, New York, also indicates that sericite was a late development in the rock, which consists of quartz, graphite, apatite, and sericitized areas.

A common occurrence of sericite is in quartzites and often sericite is the only mineral present besides quartz. In a quartzite from Marquette, Michigan (Rohn's Lake Superior Collection No. 55) sericite occurs in minute shreds in approximately parallel position. Fig. I7 is a microphotograph of a thin section of this quartzite. In the center is an original rounded sand grain with secondary enlargement of quartz on the lower side. The sericite occurs in shreds at the top and bottom of the quartz grain. It is evident that sericite was formed after the secondary enlargement and after the introduction of silica. The sericite, then, is a late development in the rock but must have formed under pressure as indicated by the parallel position of the individual crystals.

\section{SERICITE IN METAMORPHIC ROCKS WITH ORES.}

Several occurrences of sericite in metamorphic rocks which also contain ores have been studied.

In a schistose sphalerite ore from near Webb station, Mariposa county, California, sericite replaces sphalerite, pyrite, and undetermined sulphides.

In the foothill copper belt of California, which is just west of the Mother Lode, pyrite and other sulphides occur in schists, which are often sericitic. In specimens from the Ione Copper mine, near Ione, collected by Mr. A. T. Schwennesen, pyrite is later than sericite and quartz. The sericite is in part due to replacement of the quartz. This quartz represents a phenocryst of an original rhyolite or quartz-porphyry which has been converted into a sericite-schist. Ore deposition is in this case later than the metamorphism; pyrite which has replaced a lens of quartz cuts across a shred of sericite.

In the Snowstorm mine, near Mullan, Idaho, tetrahedrite occurs disseminated through a sericitic quartzite. The tetrahedrite is 
later than sericite, but the latter was evidently formed during the metamorphic period which preceded ore deposition.

In the Ione and Snowstorm specimens the sericite apparently has no connection with ore-deposition, and so these are exceptions to the general rule found in other deposits in which sericite is later than the sulphide ores. In the complex sphalerite ore from Webb late hydrothermal action was probably subsequent to metamormorphism.

SERICITE IN SCHISTOSE GYPSUM FROM MOUND HOUSE, NEVADA.

In a large gypsum quarry at Mound House, Nevada, the writer found that some of the gypsum contains sericite. This occurrence, which was recently described by the writer, ${ }^{41 a}$ may possibly throw some light upon the temperature at which sericite forms and so will be described in detail.

Anhydrite occurs at several points on the main quarry floor, and hand specimens show clearly that the transformation of anhydrite into gypsum has occurred. Microscopic study conclusively proves this point. The anhydrite is a grayish-white crystalline rock and contains a little calcite in anhedral crystals. Most of the gypsum is a compact grayish-white, massive rock. The thin sections show irregular, closely interlocking anhedra with suture-like boundaries. A little calcite is present and it is exactly like the calcite in the original anhydrite. Fig. 20 is a photograph of a thin section of the compact gypsum and Fig. I 8 one that shows the anhydrite partially altered to gypsum.

A few pieces of crystalline limestone were found loose in the quarry and at one point an impure crystalline limestone containing phlogopite, feldspar, pyrite, and several undetermined silicates, were found in the gypsum. Dark colored patches proved to contain tourmaline. The phlogopite-bearing rock probably represents impure limestone layers or inclusions in the original anhydrite. These silicates must be the result of metamorphism. The anhydrite itself is a metamorphic rock and was probably formed from a sedimentary bed of anhydrite.

41a School of Mines Quarterly, Vol. 36, p. I30 (I915). 
The most interesting rock, however, is a somewhat schistose gypsum containing sericite and a little pyrite. The schistose structure is due to a more or less parallel arrangement of gypsum subhedra and to small elongate scales of sericite which have developed along the schist plane and are plainly visible to the naked eye. Fig. I9 is a photograph of a thin section which with crossed nicols bears a strong resemblance to a figure of micaceous quartzite from Hoosac Tunnel figured by Leith. ${ }^{42}$ The gypsum is evidently the result of recrystallization under stress. As evidence of the recrystallization of the gypsum the following are noted: (I) Increase in the size of the crystals, (2) more or less parallel position of the crystals, (3) subhedral crystals instead of the original interlocking anhedra, (4) lack of strain phenomena.

The sericite is either a residual mineral from the anhydrite stage or it also is the result of recrystallization under pressure. The sericite occurs for the most part between the gypsum crystals, but in some cases it apparently cuts the gypsum. This, however, may be the result of the recrystallization of gypsum around the sericite. The calcite is penetrated by the sericite and in a few cases sericite curves around the calcite. While no sericite or muscovite was found in the original anhydrite, thin sections of the compact gypsum show a few small muscovite crystals (Fig. 20) which are different in habit from the sericite, being stouter. As the compact gypsum is the direct hydration product of the anhydrite this muscovite is probably a remnant from the metamorphic anhydrite stage at which time a rather high temperature must have prevailed. This muscovite probably furnished the material for sericite and the sericite is simply recrystallized muscovite. Taking all the facts into consideration, there can be little doubt that the sericite was formed during the recrystallization of gypsum.

The alternative is that the sericite is a residual mineral from the anhydrite stage, for it is a well-known fact that sericite is often persistent under weathering conditions. Against the view that the sericite is residual are the following arguments: (I) The sericite is only found in the schistose, recrystallized gypsum.

42 Bull. 239, U. S. Geol. Surv., plate IX. B (I905). 
(2) The compact gypsum contains muscovite of different habit from sericite. (3) The sericite crystals are in parallel position in the recrystallized gypsum while the muscovite crystals are not parallel in the compact gypsum. (4) The sericite, but not the muscovite, penetrates calcite.

If, as seems probable, sericite is a hydrothermal mineral formed during the recrystallization of gypsum, the necessary heat must have had some effect upon the gypsum. The effect of heat upon gypsum has been studied by Le Chatelier, van't Hoff, and Davis. Three compounds are formed according to the conditions of the experiment. These compounds are anhydrite, soluble anhydrite (a modification of calcium sulphate), and the half hydrate, which is $\mathrm{CaSO}_{4} \cdot \mathrm{T} / 2 \mathrm{H}_{2} \mathrm{O}$.

If the dehydration takes place below ro7.2 $2^{\circ} \mathrm{C}$., soluble anhydrite is formed, according to van't Hoff, and this may occur at a temperature as low as $63.5^{\circ} \mathrm{C}$. The resulting product is very hygroscopic and takes up water to form gypsum. Above 107.2 C. gypsum is converted into half hydrate. The half hydrate, however, is very unstable and is reconverted into gypsum, which accounts for the fact that it does not occur in nature. Total dehydration of gypsum occurs at about $190^{\circ} \mathrm{C}$. even in the presence of moist air. Heated above this temperature, so-called "dead burned" gypsum, which only sets with water with extreme slowness, is produced.

From the above data it seems almost certain that the sericite at Mound House was formed at a temperature below $190^{\circ} \mathrm{C}$. The compact gypsum formed directly from anhydrite was probably converted into the half-hydrate, which in turn took up water to form gypsum while still under pressure. This is probably the cause of the recrystallization of the gypsum. If a temperature greater than $190^{\circ} \mathrm{C}$. had even been reached, the gypsum would have been converted into "dead-burned" gypsum which is the equivalent of anhydrite.

SERICITE A LOW TEMPERATURE MINERAL.

The study of both thin sections and polished sections of a number of ores of varying type and wide distribution proves that seri- 
cite is formed after the hypogene sulphides. The only exceptions to this noted by the writer were several ores which occur in metamorphic rocks and in these cases the sericite belongs to the metamorphic period and so has connection with the ore deposition.

The microscopic study of various types of ores convinces me that in the great majority of cases ore-minerals, especially sulphides, are formed later than the gangue minerals, which are mostly silicates and silica. This is even true for the magmatic sulphides as shown by the writer. ${ }^{43}$ The only hypogene silicates later than the sulphides that I have been able to find are chlorite, sericite, and tremolite. There may be some exceptions, but I believe further study will prove the truth of the statement that the sulphides are in general later than the hypogene silicates.

When we have the evidence that a series of hypogene sulphides have been formed at gradually decreasing temperature as at Butte, and that sericite is later than these sulphides, we are forced to the conclusion that sericite is formed at a very late stage in mineralization. In fact, I can find no evidence that any hypogene mineral is later than sericite.

Of course there is not definite evidence that sericite is a late, low temperature mineral in every occurrence studied, for often only a few minerals occur, and the intermediate stages of mineralization are lacking.

On careful analysis the published evidence that sericite is contemporaneous with the sulphides or is formed at an early period of mineralization is not convincing; i.e., there is no clear evidence supported by microphotographs.

Probably few will doubt that in some cases sericite is a low temperature mineral. The next question that presents itself is the temperature range of sericite. Dr. F. B. Laney and Professor C. F. Tolman, jr., in conversation with the writer, while admitting his microscopic evidence, both expressed the opinion that sericite ranges from rather high temperature to low temperature. While further study is necessary to settle this point it is worth while to consider all the evidence bearing on this point.

43 Econ. Geol., Vol. 9, p. 389 (IgI4). 
For my part, I believe that sericite has a rather restricted range. Its occurrence in high temperature and medium temperature deposits is easily accounted for, if we assume gradually decreasing temperature. Only by making such an assumption can we account for the series of replacements of one mineral by another which the microscope proves to have taken place.

The only serious objection to the invariable low temperature origin of sericite is one suggested by Professor Tolman, which is the failure of the earlier solutions to effect alteration of the wall rocks. This brings up an interesting point, but one difficult to settle. One possible explanation is that the period of vein formation and ore-deposition is a relatively brief one, even though the stages are often well marked, and that the reactions involved in sericitization are rather sluggish. At any rate the microscopic examination of ores which are typical and not exceptional types, proves that the sericitization did not take place until towards the close of the hydrothermal period. The explanation remains to be found.

IS SERICITE A PRODUCT OF WEATHERING AND STATIC METAMORPHISM?

The proof that sericite is a rather low temperature mineral makes it necessary to inquire into its possible origin from cold meteoric waters.

Paige $^{44}$ finds sericite later than turquois in the Burro mountains (N. M.) deposit, and considers that it may be formed by downward circulation of carbonated waters.

Hickling ${ }^{45}$ in discussing the china-clays of Cornwall says:

"Atmospheric weathering' is the cause of the 'kaolinization' of the granite. Secondary muscovite (sericite) represents the first stage of the process and is a normal product of the weathering feldspars."

Lindgren ${ }^{48}$ believes that this sericite is due to previous alteration by thermal waters and also expresses the opinion:

44 Econ. Geol., Vol. 7, p. 388 (1912).

45 Trans. Inst. Min. Eng. (London), Vol. 36, p. 31 (Ig08-9).

46 “ Mineral Deposits," p. 299, 305 (I9r3). 
"It is not believed that muscovite or sericite results from weathering."

As arguments against the idea that sericite is the product of weathering the following may be mentioned.

The weathering of various igneous and metamorphic rocks results in a loss of potash $\left(\mathrm{K}_{2} \mathrm{O}\right)$ which amounts to as much as 92 per cent. in some cases. This is shown conclusively by Merrill. ${ }^{47}$ Sericitization on the other hand results in a gain of potash. ${ }^{48}$

Kaolinite, not sericite, is produced by the action of carbonated water upon feldspars. ${ }^{49}$

Although often rather resistant, muscovite and sericite are slowly attacked in the zone of weathering.

Sericite is often absent in weathered granites. This is of more significance than the presence of sericite in certain weathered granites, for the sericite may have been formed by a hydrothermal process prior to weathering. In a suite of granites, granite-pegmatites, and granite-aplites from the Headquarter mountains near Granite, Oklahoma, weathering is evident in all specimens which were taken from the surface boulders and not from quariried material. The feldspars are much altered but no sericite could be found. The alteration product is an indefinite white, almost opaque, substance which is probably kaolinite or possibly its colloidal equivalent. The alteration begins on the outside of the feldspar and proceeds toward the interior. Sericitization on the other hand usually begins in the interior of the feldspar.

Lindgren ${ }^{50}$ believes that sericite found in various rocks of the Clifton-Morenci district, Arizona, remote from the ores, was formed by what he calls "common hydrometamorphism "51 which he defines thus: "This which is also described as static metamorphism, includes the changes effected under the influence of ordinary percolating waters of a moderate depth, but distinctly below the zone of active oxidation."

47 “Rocks, Rock-weathering and Soils," p. I85 et seq.

48 Steidtmann, Econ. GeoL., Vol. 3, p. 38I (1908).

49 Müller, “Tschermak's Min. Mitth.,"Jahrg. 1877, p. 47.

${ }^{50}$ Prof. Paper 43, p. I25 (1905).

51 This term was first used by Lindgren in his monograph on the "GoldQuartz Veins of Nevada City and Grass Valley" (I7th An. Rep. U. S. Geol. Surv., pt. 2, p. 9I, I896). 
If sericitization is a late stage of mineralization, there is no reason why it should invariably follow metallization, nor, on the other hand, why it should necessarily be preceded by metallization. Hydrothermal alteration is assuredly not always accompanied by ore-deposition. For it is a well-known fact that most quartz veins are barren.

It must be recognized that some minerals, especially those in sedimentary rocks, are formed below the zone of oxidation by static metamorphism or diagenesis. Andrée ${ }^{52}$ limits the term diagenesis to changes brought about by vadose or connate solutions which do not introduce materials from an extraneous source. The process, then, is one mainly of recrystallization and induration, at least for the sedimentary rocks. With the limitation that no material is introduced from outside sources it may be doubted whether any changes take place in the silicates of igneous rocks below the zone of oxidation. There remain to be considered changes caused by meteoric waters in advance of oxidation but there are few available data on this phase of metamorphism.

In a microscopic study of copper ores from the Engels mine in Plumas county, California, the writer has given special attention to this point. The original ore consists of magmatic bornite and chalcopyrite disseminated through a norite-diorite.. As far as can be ascertained, the only minerals formed in advance of oxidation by descending solutions are chalcocite and veinlets of quartz. Sericitization is independent of, and preceded by, the formation of supergene chalcocite. The sericite occurs in sharp, well defined crystals of appreciable size and not in the indefinite scales and fibers so characteristic of this mineral. This in itself is an argument against the supergene origin of the sericite, for if it does occur as a supergene mineral one would expect to find it in crystal aggregates still finer than those of hydrothermal origin.

There is no clear evidence that sericite is formed by meteoric waters either in the oxidized zone or below it, but more observations are needed before positive statements can be made.

A plausible explanation of why sericite is not formed by meteoric waters is that hydrostatic pressure or stress is necessary ${ }^{52}$ Geol. Rundschau, Bd. II., pp. 61-74, I17-130. 
for the development of sericite. If fluorine is required for the formation of sericite as is suggested by Spurr, ${ }^{53}$ pressure may be necessary to retain the fluorine. This does not necessarily mean that sericite contains fluorine. For the fluorine may simply act as a catalyzer.

\section{THE HYDROTHERMAL ORIGIN OF SERICITE.}

The greatest development of sericite is in altered wall-rocks of ore-bearing veins and in metamorphic rocks. The ores we know are, for the most part, hydrothermal in origin and de Lapparent's ${ }^{54}$ work on the porphyroids indicates that the sericite in metamorphic rocks is not the product of dynamic metamorphism, but is due to the slow circulation of solutions, which means that it is hydrothermal. The hydrothermal origin of sericite is emphasized by some of the recent students of ore-deposits among whom are Lindgren, ${ }^{55} \mathrm{Kirk},{ }^{56}$ and Steidtmann. ${ }^{57}$

Among arguments in favor of the hydrothermal origin of sericite the following may be advanced:

Hydrothermal alteration usually involves a marked increase in the potash content.

The occurrence of sericite suggests that it develops only under conditions of moderate pressure or stress.

Sericitization in several ore-deposits precedes the formation of supergene chalcocite.

Kaolin near the surface is often found to pass into sericite at depth.

SUMMARY AND CONCLUSIONS.

Sericite, though very similar to, if not identical with, muscovite in chemical composition, may be considered a distinctive mineral and not simply a variety of muscovite.

Sericite not only replaces silicates but also various sulphides

53 Prof. Paper 42, U. S. Geol. Surv., p. 232 (1905).

54 Loc. cit.

${ }_{55}$ "Mineral Deposits," p. 299 (I9r3).

56 Econ. GeoL., Vol. 7, p. 67 (I9II).

${ }^{57}$ ECon. Geol., Vol. 3, p. 38I (1908). 
such as pyrite, chalcopyrite, bornite, chalcocite, covellite, galena, and sphalerite.

Sericite is a rather low-temperature mineral formed at, or towards, the close of the hydrothermal period. Few, if any, of the hypogene minerals are later than sericite.

Sericite is later than hypogene chalcocite, but earlier than supergene chalcocite.

Sericite in metamorphic rocks is also formed at a late stage equivalent to the hydrothermal stage of ore-deposition.

Sericite apparently does not form in the zone of weathering and probably not in the zone of static metamorphism. 